\title{
UTILIZING EXHAUST GASES OF DIESEL ENGINES IN DRYING GRAIN RICE
}

\author{
Shetawy, M.A. El-Said ${ }^{1}$ and Abo El-Naga, M. H. M. ${ }^{2}$ \\ ABESTRACT
}

In Egypt, rice crop occupies the first rank in area cultivated as the main food.Percentage of moisture in grain is up to $24 \%$ with mechanical harvesting of rice crop. For safe storage of rice seeds, it is required to reduce the humidity to $14 \%$. Due to weather changes it is difficult to dry by the sun. Therefore, the main objective of this study is the use of thermal energy lost with the exhaust gases of diesel engines in drying rice seed. The suggested drying unit is simple made from local raw materials, comprising: a fan to generate air stream carry the heat, heat exchanger for the exhaust gases installed behind the fan, a drying container. Drying tests were conducted using the Sakha 101, whereas the average weight of each sample in drying process was $25 \mathrm{~kg}$, the average humidity was $20.4 \%$, the average temperature of air was $24.6{ }^{\circ} \mathrm{C}$ and the average relative humidity of the air was $65.7 \%$. The experiments have shown the following results: The highest temperature of input drying air was 42.2 ${ }^{\circ} \mathrm{C}$, energy received by drying air was $9.62 \mathrm{MJ} / \mathrm{h}$ and capacity of drying unit was 0.074 ton/h achieved with drying air flow rate $07.65 \mathrm{~m}^{3} / \mathrm{min}$.

\section{INTRODUCTION}

$\mathrm{M}$ any researchers and reports mentioned that roughly $30 \%$ energy of the burnt fuel is lost though the exhaust system and roughly $30 \%$ is lost through the cooling system of the internal combustion engine. These waste energies could be used for drying of agricultural products. An attempt was made for the utilization of enginewaste heat for grain drying with a small dryer bed area and grain depth.

Soemangat et al., (1973). They concluded that the energy requirement for grain drying can be minimized with the use of a large bed area, low air temperature and low air velocity.

${ }^{1}$ Lect. Agric. Eng. Dept. Fac. of Agric., Al-Azhar Univ. Egypt.
${ }^{2}$ Senior Res., Agric.Eng. Res. Inst., Dokki, Giza, Egypt. 
Michael and Ojha (1978) revealed that drying is the universal method of conditioning grain by removing moisture to level that is in equilibrium with normal atmospheric air in order to preserve its quality and nutritive value as food and its viability for seeds. Also, they reported that there are three methods of drying grain with the use of air. (a) Unheated or natural air-drying; (b) unheated air drying with supplemental heat; and (c) heated air-drying.

Brooker et al. (1978) stated that several parameters influence the time required to reduce the product to the desired moisture content for a particular grain. These include air temperature, air relative humidity, airflow, original moisture content, and final moisture content. These parameters are considered in the design of the equipment and are manipulated in its operation to dry the grain within the time limit selected. Also, they mentioned that the operator better controls drying operations are when heated air is used for drying.

Li and Morey (1984) developed an equation to determine thin - layer drying rates for yellow dent corn as affected by drying air temperature, air flow rate, initial moisture content, and relative humidity. They found that drying air temperature had the greatest effect on drying rates. Initial moisture content also influences drying rates. Air flow and relative humidity had smaller effects.

Abe et al. (1992) carried out preliminary study on the utilization of engine-waste heat for grain drying with a dryer capacity of $140 \mathrm{~kg}$ of rough rice. They conducted a single test and less kernel breakage was found than rice dried in the sun or dried too rapidly with high temperature air. They used a separate power source (electric motor) to drive the dryer fan which was a serious drawback of their work. This forced them to cover the whole engine with extra housing which is difficult to make and handle and, therefore, impractical.

Basunia et al. (1996a, 1997) reported the simulation result of the enginewaste heated rough rice dryer for a shallow depth of grain beds (10 - 40 $\mathrm{cm}$ ) and validated the accuracy of the partial differential equation model (PDE) in low temperature drying of rough rice using engine waste heat. This time fan was directly coupled with the engine camshaft without any extra covering for the whole engine. 
Basunia and Abe (1996b) also reported the energy saving in intermittent drying of shallow depth $(10-40 \mathrm{~cm})$ of grain bed using engine waste heat. They concluded that further study should be carried out with a greater depth of rough rice.

Ojha and Michael (1996) mentioned that slow drying is recommended to preserve the viability and wholeness of the grain. A heated air temperature of $43^{\circ} \mathrm{C}$ is recommended for drying paddy. High drying air temperature will not only expose the grain to high temperature but also dry the outer surface of the grain faster than the moisture can move from the core to the grain surface. This uneven dryness of the grain results in internal stresses that cause the grain crack. The same is true when water is poured on a dry grain as rain on grain during sun drying. These cracks on the grain are not externally visible but manifest during milling as low grain recovery and high percentage of breakage. About $30 \%$ of heat produced by combustion of fuel in a diesel engine is carried away by exhaust gases. This waste heat can be utilized in mechanical drying of crops which offers the advantage of timeliness in drying reducing handling losses, maintaining grain quality, and better control over the drying process. Many attempts had been made to utilize engine cooling waste heat for grain drying.

Soemangat et al. (1973) made an attempt for the utilization of engine cooling waste heat for grain drying with different bed area dryers and grain depth. They concluded that the energy requirement for grain drying can be minimized with the use of a large bed area, low air temperature and low air velocity. That research was used to minimize post-harvest losses and for effective utilization of energy resources for crop drying. It had also been demonstrated that, compared to other drying methods, near ambient drying by raising the drying air temperature few degrees above ambient is potentially the most energy efficient drying technique. Basunia et al.(1997) reported the utilization of engine cooling waste heat of petrol engine for grain drying with comparatively larger bed area. A fan was directly coupled with the engine crankshaft to supply the engine waste heat to the dryer. They found that the heat required for drying per $\mathrm{kg}$ of grain was $3.26 \mathrm{~kJ} / \mathrm{h}$ with continuous supply of about $93 \%$ of the waste heat of engine cooling system to the drying air. They also reported 
that the waste heat was sufficient to increase the temperature of the ambient air from $7^{\circ} \mathrm{C}$ to $12^{\circ} \mathrm{C}$ at an air flow rate of 5.7 to $8.8 \mathrm{~m}^{3} / \mathrm{min}$. Akhter et al. (2007) found that a maximum exhaust gases temperature of the engine was obtained as $110^{\circ} \mathrm{C}$ at a speed of 1500 r.p.m. and load of $6.5 \mathrm{~kg}$. The flow rate of exhaust gases at this condition was about $7.7 \mathrm{x}$ $10^{-4} \mathrm{~m}^{3} / \mathrm{sec}$. Under the above engine running conditions, the temperatures of exhaust gases at inlet and outlet of heat exchanger were $110^{\circ} \mathrm{C}$ and $100^{\circ} \mathrm{C}$ respectively and those of atmospheric air were $27^{\circ} \mathrm{C}$ and $50^{\circ} \mathrm{C}$ respectively. During 1 hour drying, the average $\mathrm{MC}$ of paddy along different horizontal layers decreased to $12-18 \%$ from initial MC of $26.1 \%$. The average MC of paddy along different vertical layers was almost equal at any particular time of drying and reduced to about $15 \%$ from $26.1 \%$ for 1 hour continuous drying. Average MC of paddy for 1 hour continuous drying by hot air heated in a heat exchanger by the diesel engine exhaust gases was determined as $15 \%$ from initial MC of $26.1 \%$. The dried paddy volume with the MC of $15 \%$ may be stored for a long time.

Basunia and Abe (2008) found that the engine-waste heat was sufficient to increase the drying air temperature 7 to $22^{\circ} \mathrm{C}$ at an air flow rate of 12.6 to $1.2 \mathrm{~kg} / \mathrm{min}$ with the average ambient temperature and relative humidity were 26.7 and $71.1 \%$. However, the result has shown promise for this type of grain drying unit, especially in major rice growing regions, where the same engines are used for pumping irrigation water and rice milling purposes.

The present study was conducted with the following objectives:

- To estimate the availability of engine-waste heat which can be utilized for drying seeds at variables of engine speed and air flow rate of fan.

- To study the performance of drying unit at variables of engine speed, air flow rate and depth of seed bed of rice seeds.

\section{MATERIAL AND METHODS}

\section{Materials:}

All drying processes were carried out using rice crop variety of (Sakha 101) at moisture content $20.4 \%$ and atmospheric air temperature $24.6{ }^{\circ} \mathrm{C}$ with the waste - exhaust gases heat from diesel engine by using a simple 
drying unit That fabricated and tested at a private workshop in Mansoura City, Dakahliea Governorate during two seasons 2009/2010.

The drying unit consisted of the following parts:

\section{a. The fan:}

A fan with four blades was fixed in front of heat exchanger. It was powered from the engine camshaft through coupled wheel with a diameter of $12.5 \mathrm{~cm}$, while the fan wheel diameter was $17.5 \mathrm{~cm}$. The total fan width was $25 \mathrm{~cm}$ and diameter was $25 \mathrm{~cm}$.

\section{b. Heat exchanger:}

Heat exchanger transfers the heat from exhaust gases to air stream with fan. In fig.2, schematic view shows the components of heat exchanger. Two cases were fabricated from galvanized steel with thickness of $2 \mathrm{~mm}$, width of $5 \mathrm{~cm}$, length of $12 \mathrm{~cm}$, and height of $15 \mathrm{~cm}$. The cases was linked by four copper pipes at length of $10.5 \mathrm{~cm}$ and diameter of $2.25 \mathrm{~cm}$. In addition to six aluminum plates at dimensions of $20 \times 15 \mathrm{~cm}^{2}$ as length and width and thickness of $3 \mathrm{~mm}$. These plates were fixed on the tubes at equal distance to increase the heat transfer area and efficiency.

\section{c. The drying bin:}

The drying bin is shown in fig.1; schematic prototype of a drying unit. It was fabricated from galvanized steel with thickness of $1 \mathrm{~mm}$, base area of $25 \times 50 \mathrm{~cm}$, and height of $25 \mathrm{~cm}$, inside the bin five shelves were fixed upon five drying plates of a rectangular shape having width of $20 \mathrm{~cm}$, length of $45 \mathrm{~cm}$ and height of $10 \mathrm{~cm}$. The base of plate was fabricated from wire screen to prevent force on the seeds and allow hot air to pass through the grains. The bin was supported by mild steel rod frame with a diameter $5 \mathrm{~mm}$. All sides were fabricated from galvanized sheet with height of $10 \mathrm{~cm}$. All interior surfaces of drying bin were stuffed by glass wool to insulate heat inside bin and prevent heat losses by conveying or radiation.

\section{Waste-exhaust heat source:}

The waste-exhaust heat was generated from a diesel engine, air cooled, four-stroke cycle, having a horse power from 5.76 to $6.72 \mathrm{~kW}$ at from 1500 to 1750 r.p.m, respectively was used for this study. 
PROCESS ENGINEERING

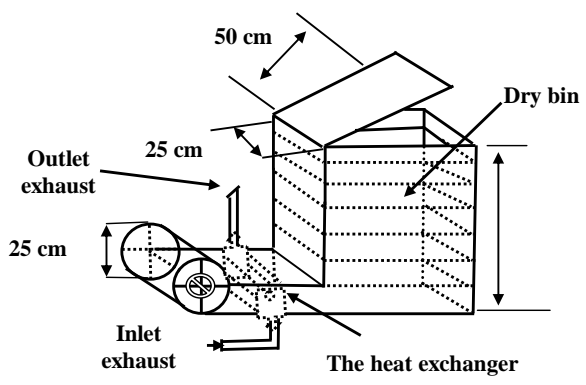

Fig.1: Prototype of the drying unit.

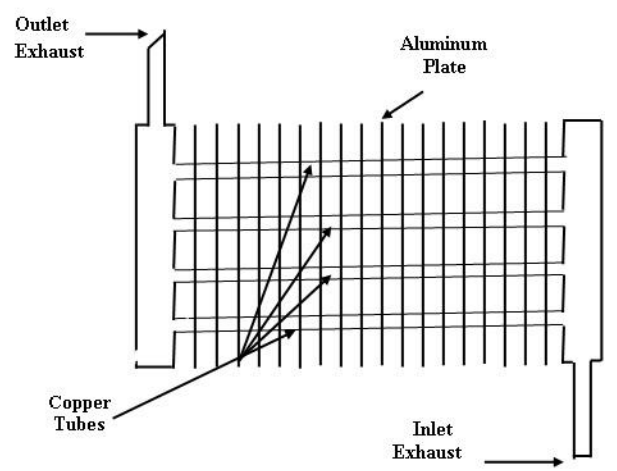

Fig.2: The heat exchanger.

\section{Methods:}

All experiments were performed with the following procedures: average sample mass of rough rice was $25 \mathrm{~kg}$ was dried by waste - exhaust heat to reduce the moisture content of grains from $20.4 \%$ w.b. to approximately $13.6 \%$ w.b. The exhaust gasses temperature generated with engine was measured under different engine speeds from 750 to 1550 r.p.m.by using a temperature meter model (ERO, Electronic. MemocalR 81) connected to an iron - constant a thermocouple type $(\mathrm{T})$ to measure air and grain temperatures for the drying systems. The urgent measuring check points for the drying systems were in the air passing through the exchanger heat system (just before the entrance of the drying bin seeds). Also air stream velocity generated by the fan was measured by the anemometer; which was made in Japan by Satake Co., Speed measurement ranged from 0 to $50 \mathrm{~m} / \mathrm{s}$. The moisture content of rice seeds was measured by using electronic moisture meter (GANN Hydromel G 86), made in Western 
Germany and confirmed by the oven drying method, according to the standard procedure of the Japanese Society of Agricultural Machinery.

\section{Waste-exhaust heat:}

Diesel internal combustion engines are of about 30\% efficiency. From the energy derived from burnt fuel, another $30 \%$ is lost through the exhaust, radiation. Friction accounts for $10 \%$, and the remaining $30 \%$ is lost through the cooling system. The heat energy required to heat up the drying air is mostly derived from the engine exhaust system heat. The exhausting load $W_{c}$ of the engine at any given r.p.m. can be determined by the following equation. (Basunia and Abe 2008)

$$
W_{c}=\eta_{c} \times \beta \times c_{f} \times \eta_{f} \times P_{b},
$$

Where:

$\eta_{c}=$ is the exhausting system efficiency, $\%$.

$W_{c}=$ is the waste heat energy released from the engine exhausting system to the drying air, $\mathrm{MJ} / \mathrm{h}$

$\beta=$ is the specific fuel consumption, $\mathrm{kg} /(\mathrm{kW} \cdot \mathrm{h})$

$C_{f}=$ is the calorific value of fuel, $(10000 \mathrm{MJ} / \mathrm{kg})$

$\eta_{f}=$ is the fuel exhaust efficiency, $30 \%$.

$P_{b}=$ is the break power of the engine at any r.p.m. kW.

Substitution of the values of the different parameters in equation (1) for the engine used in this experiment led to the following equation :

$$
w_{C}=3.5006 p_{b}
$$

The total heat energy $W_{r}$, to be utilized to heat the drying air at any given r.p.m. of the engine was calculated from the following equation

$$
w_{r}=0.06 . Q . c . \rho \cdot\left(t_{d}-t_{a}\right),
$$

Where:

$W_{r}=$ is the amount of heat energy received by the drying air, $\mathrm{MJ} / \mathrm{h}$ $0.06=$ is the units conversion factor.

$Q=$ is the volume flow rate of drying air, $\mathrm{m}^{3} / \mathrm{min}$.

$\mathrm{c}=$ is the specific heat of drying air, $\left(1.006 \mathrm{~kJ} /\left(\mathrm{kg}^{\circ}{ }^{\circ} \mathrm{C} \cdot\right)\right.$

$\rho=$ is the density of drying air, $\left(1.184 \mathrm{~kg} / \mathrm{m}^{3}\right)$.

$t_{d}$ and $t_{a}=$ are the temperatures of drying air and ambient air, respectively. 


\section{RESULTS AND DISCUSSION}

\section{Engine performance:}

Data in figs. 3 and 4 shows that increasing in engine speed increased the drying air velocity and flow rate from 1.56 to $4.25 \mathrm{~m} / \mathrm{s}$ and from 2.81 to $7.65 \mathrm{~m}^{3} / \mathrm{min}$ with increasing of engine speed from 750 to 1550 r.p.m. respectively. Therefore, the highest value of air drying velocity of 4.25 $\mathrm{m} / \mathrm{s}$ and air drying flow rate of $7.65 \mathrm{~m}^{3} / \mathrm{min}$ were achieved with engine speed of 1550 r.p.m.

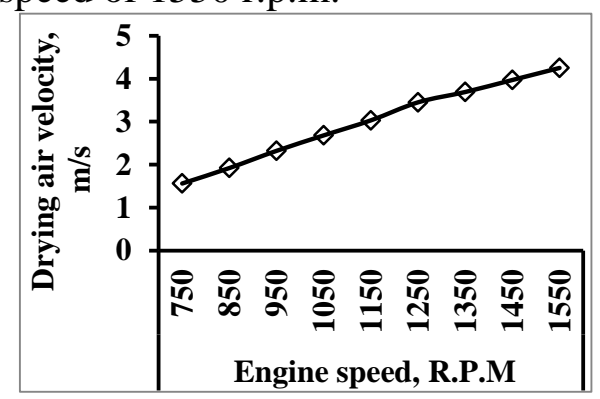

Fig.3: Effect of engine speed on drying air velocity.

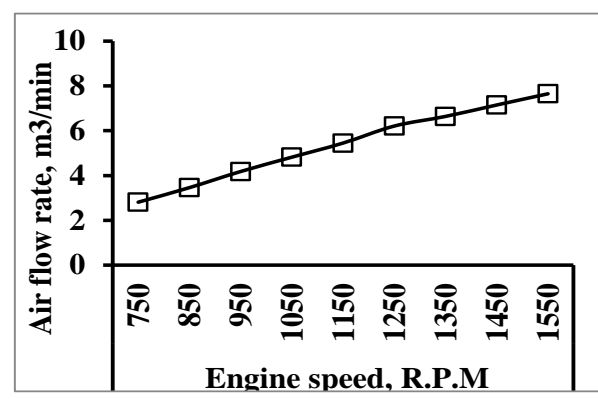

Fig.4: Effect of engine speed on drying air flow rate.

\section{Effect of air flow rate on the performance of the drying unit:}

At steady of engine speed and air flow rate, the average of temperatures measured at back of exchanger heat is assumed as the drying air temperature for the energy calculation. Data in fig.5 show that increasing air flow increased the temperature at input and output of drying air with varying degrees. The inlet drying air temperature increased from 32.6 to $42.2^{\circ} \mathrm{C}$ at increasing air flow rate from 2.81 to $7.65 \mathrm{~m}^{3} / \mathrm{min}$. Also the rise of inlet drying air temperature had the same trends under the same previous conditions. The inlet drying air temperature increased from 8.0 to $17.6{ }^{\circ} \mathrm{C}$ when increasing air flow rate from 2.81 to $7.65 \mathrm{~m}^{3} / \mathrm{min}$. On the other side, the outlet drying air temperature values tend to increase from 30.97 to $37.56{ }^{\circ} \mathrm{C}$ the increase of air flow rate from 2.81 to $7.65 \mathrm{~m}^{3} / \mathrm{min}$. Also the rise of outlet drying air temperature increased from 6.37 to 12.96 ${ }^{\circ} \mathrm{C}$ at increasing of air flow rate from 2.81 to $7.65 \mathrm{~m}^{3} / \mathrm{min}$. Therefore, the highest values of the input and output drying air temperature and the rise of air drying temperature were (42.2 and $\left.37.56{ }^{\circ} \mathrm{C}\right)$ and $(17.6$ and 12.96 ${ }^{\circ} \mathrm{C}$ ) respectively achieved with air flow rate of $7.65 \mathrm{~m}^{3} / \mathrm{min}$. Meanwhile, the lowest values of the inlet and outlet drying air temperature and the rise of air drying temperature were $\left(32.6\right.$ and $\left.30.97{ }^{\circ} \mathrm{C}\right)$ and $\left(8.0\right.$ and $\left.6.37{ }^{\circ} \mathrm{C}\right)$ respectively, achieved with air flow rate of $2.81 \mathrm{~m}^{3} / \mathrm{min}$. The energy 
released as waste heat from the exhaust gases were estimated as measured heat energy received by drying air under different air flow rates from 2.81 to $7.65 \mathrm{~m}^{3} / \mathrm{s}$, and average ambient temperature of $24.6{ }^{\circ} \mathrm{C}$ and relative humidity $65.7 \%$.

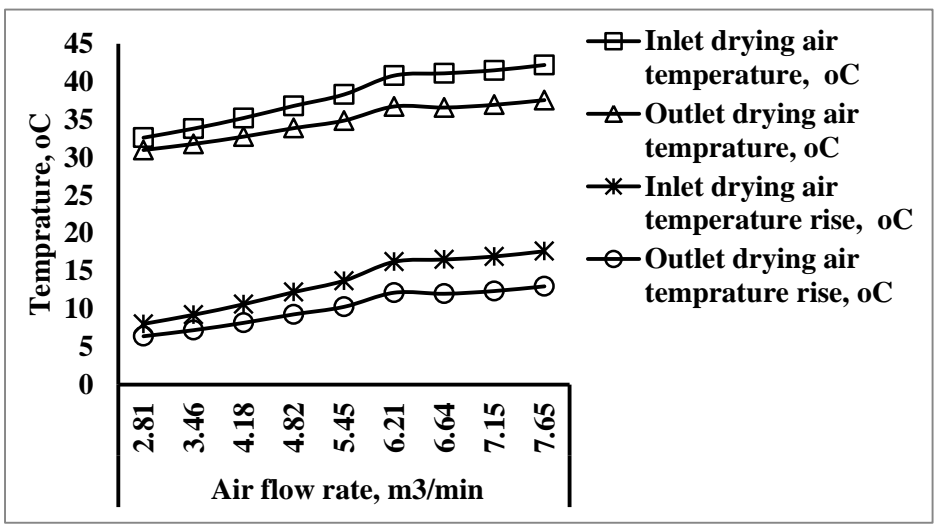

Fig.5: Effect of different air flow rates on temperature of drying air.

Data in figs.6 and 7 showed the effect of air flow rate on the energy received and efficiency by drying air. The results indicated that the value of energy received by drying air increased from 1.61 to $9.62 \mathrm{MJ} / \mathrm{h}$ with increasing of air flow rate from 2.81 to $7.65 \mathrm{~m}^{3} / \mathrm{s}$. Also the efficiency of energy received by drying air increased from 29.5 to $83.93 \%$ under the same previous conditions. Therefore, the highest value and efficiency of energy received by drying air were $9.62 \mathrm{MJ} / \mathrm{h}$ and $83.93 \%$ achieved with air flow rate of $7.65 \mathrm{~m}^{3} / \mathrm{min}$. Meanwhile the lowest value and efficiency of energy received by drying air were $1.61 \mathrm{MJ} / \mathrm{h}$ and $29.5 \%$ achieved with air flow rate of $2.81 \mathrm{~m}^{3} / \mathrm{min}$.

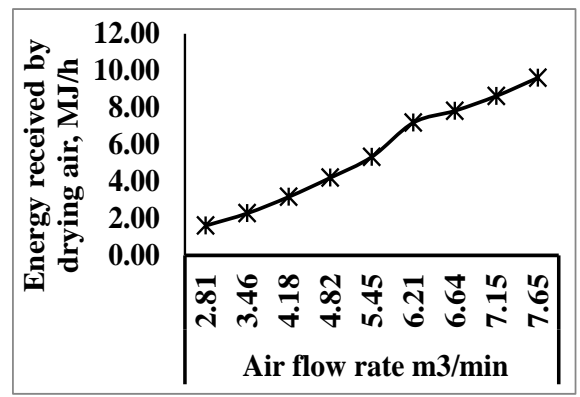

Fig.6: Effect of air flow rate on energy received by drying air.

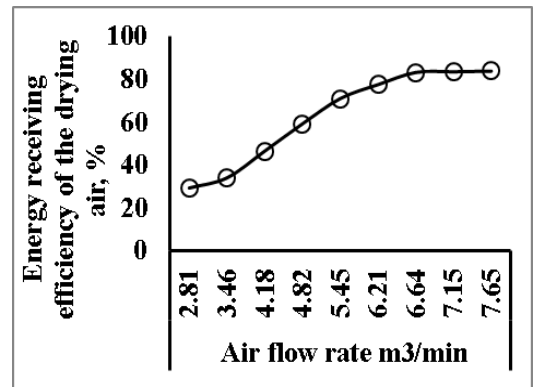

Fig.7: Effect of air flow rate on energy received efficiency by drying air. 


\section{Time and energy consumed in the drying process:}

The data in figs. 8 and 9 indicated the effect of different air flow rates on the drying time and capacity of drying unit. The results indicated that the drying time decreased from 50.83 to $13.46 \mathrm{~h} /$ ton with increasing of air flow rate from 2.81 to $7.65 \mathrm{~m}^{3} / \mathrm{min}$. Meanwhile the capacity of drying unit increased from 0.020 to 0.074 ton/h with increasing of air flow rate from 2.81 to $7.65 \mathrm{~m}^{3} / \mathrm{min}$. Therefore, the highest value of drying time and capacity of drying unit were $50.83 \mathrm{~h} /$ ton and $0.074 \mathrm{ton} / \mathrm{h}$ achieved with air flow rates of 2.81 and $7.65 \mathrm{~m}^{3} / \mathrm{min}$. Meanwhile the lowest values were $13.46 \mathrm{~h} /$ ton and $0.020 \mathrm{ton} / \mathrm{h}$ achieved with air flow rate of 7.65 and 2.81 $\mathrm{m}^{3} / \mathrm{min}$ respectively.

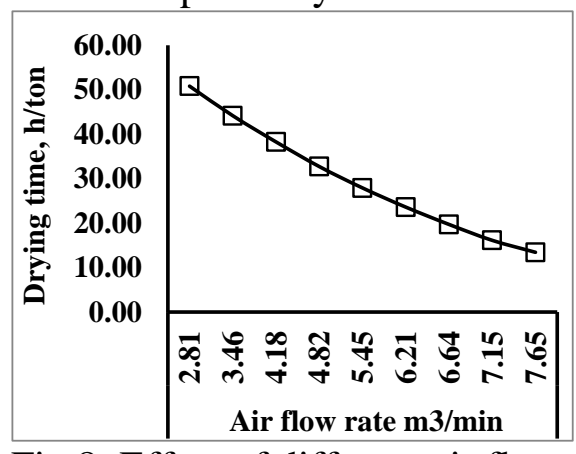

Fig.8: Effect of different air flow rates on drying time.

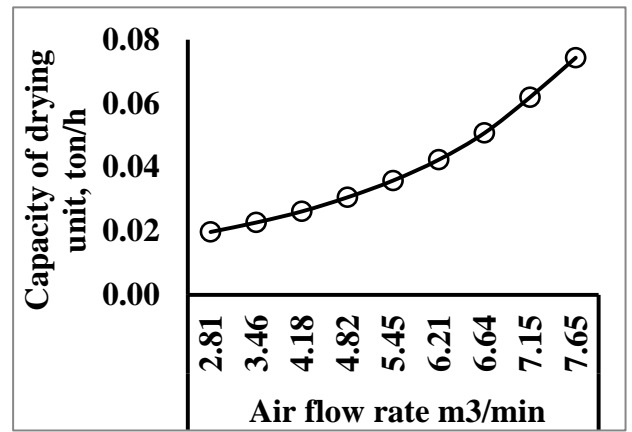

Fig.9: Effect of different air flow rates on capacity of drying unit.

\section{CONCLUSIONS}

- The highest value of the inlet and outlet drying air temperatures and the rise of air drying temperature were $\left(42.2\right.$ and $\left.37.56{ }^{\circ} \mathrm{C}\right)$ and $(17.6$ and $12.96{ }^{\circ} \mathrm{C}$ ) respectively, achieved with air flow rate of $7.65 \mathrm{~m}^{3} / \mathrm{min}$. Meanwhile the lowest values of the inlet and outlet drying air temperature and the rise of drying air temperature were (32.6 and $30.97{ }^{\circ} \mathrm{C}$ ) and $\left(8.0\right.$ and $\left.6.37^{\circ} \mathrm{C}\right)$ respectively, achieved with air flow rate of $2.81 \mathrm{~m}^{3} / \mathrm{min}$.

- The highest value and efficiency of energy received by drying air were $9.62 \mathrm{MJ} / \mathrm{h}$ and $83.93 \%$, achieved with air flow rate of $7.65 \mathrm{~m}^{3} / \mathrm{min}$. Meanwhile the lowest value and efficiency of energy received by drying air were $1.61 \mathrm{MJ} / \mathrm{h}$ and $29.5 \%$ achieved with air flow rate of $2.81 \mathrm{~m}^{3} / \mathrm{min}$. 
- The highest value of drying time and capacity of drying unit were $50.83 \mathrm{~h} /$ ton and $0.074 \mathrm{ton} / \mathrm{h}$, achieved with air flow rates of 2.81 and $7.65 \mathrm{~m}^{3} / \mathrm{min}$. Meanwhile the lowest values were $13.46 \mathrm{~h} / \mathrm{ton}$ and $0.020 \mathrm{ton} / \mathrm{h}$, achieved with air flow rate of 7.65 and $2.81 \mathrm{~m}^{3} / \mathrm{min}$ respectively.

\section{Recommendations:}

The best weighted rate of drying was about $74 \mathrm{~kg} / \mathrm{h}$ at average ambient temperature of $24.6{ }^{\circ} \mathrm{C}$ and relative humidity $65.7 \%$, to reduce the moisture content level of rice seeds from $20.4 \%$ w.b. to approximately $13.6 \%$ w.b. at drying air flow rate of $7.65 \mathrm{~m}^{3} / \mathrm{min}$.

\section{REFERENCES}

Abe, T., C. E. Ofoche, Y. Hikida and J.Yamashita (1992). Utilization of engine-waste heat for grain drying. Proceedings of the International Agricultural Engineering Conference, Bangkok, (IV), 1147-1154.

ASAE yearbook standard (1983). Pub. by the Am. Soc. of Ag.Eng.,St. Joseph, Mich., USA.

Basunia, M. A., T. Abe, and Y. Hikida. 1996a. Simulation of engine wasted heat stationary-bed rough rice dryer. Agricultural Mechanization in Asia, Africa and Latin America, 4(27): 37-45, 48.

Basunia, M. A. and T. Abe. 1996b. Energy savings in intermittent drying of rough rice using engine waste heat. Agricultural Engineering Journal, $5(3$ \& 4): 149-159.

Basunia, M. A. Abe, T. and Y. Hikida (1997). Utilization of enginewaste heat for paddy drying and validation of stationary-bed model invariable low temperature drying. AMA: Africa and Latin Am., 28 (4), : 47-52.

Basunia, M.A and T. Abe (2008). Performance study of a small engine waste heated bin dryer in deep bed drying of paddy. Ag. Eng. I: the CIGR Ejournal Manuscript EE 08 015. Vol. X. Dec., 2008: 1- 11.

Brooker, D. B.; F. W. Baker - Arkema and C. W. Hall (1978). Drying cereal grain. $2^{\text {nd }}$ Ed. AVI pub. Co., Westport, Conn., INC., USA.: 
Li, H. and R. V. Morey (1984). Thin-layer drying of yellow dent corn. Trans. ASAE: 581-585.

Ojha, T. P. and Michael, A. M. (1996). Principles of Agricultural Engineering., Vo. I, 3 rd Edi. Jain Broth., New Delhi, India.

Michael, A. M. and T. P. Ojha (1978). Principles of agricultural engineering, Vol. 1, Farm power and machinery, Farm building and post - harvest technology. 873, East Park Road, Koral Bagh, New Delhi - 110005 .

Shamim Akhter, Md., Md. Nurun Nabi and Zakia Afroz (2007). Recovery of waste heat from engine exhaust for utilization in a paddy dryer (ICME2007) December 2007, Dhaka, Bangladesh.: 2931.

Soemangat, M. L. Esmay and W. J. Cahanceller (1973). Rice drying with engine waste heat. AMA: in Asia, Africa and Latin Am., A., : 80-85.

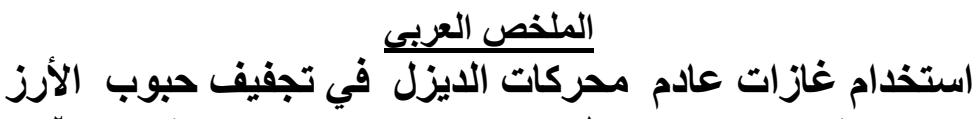

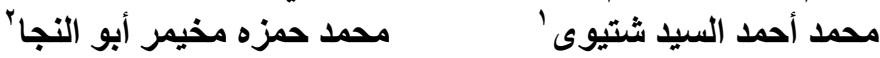

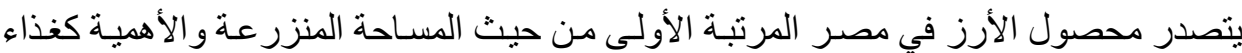

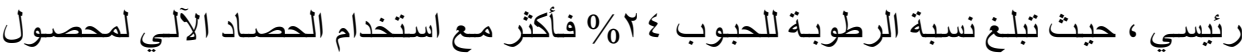

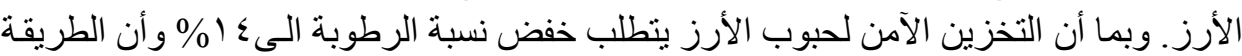

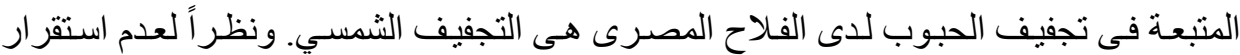
الظروف الجوية وتز امن سقوط الأمطار و انخفاض درجة حرارة الجو خلال موسم حصـاد الأرز

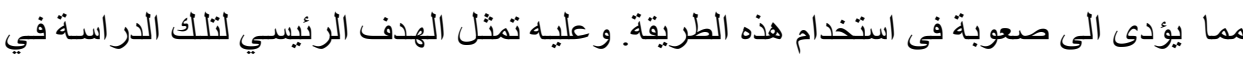

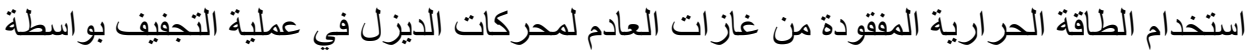

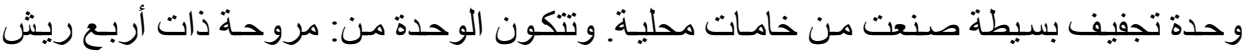
لتوليد تيار من الهو اء ومبدل حر ارى لغاز ات العادم مثبت خلف المروحة وو وعاء التجفيف.

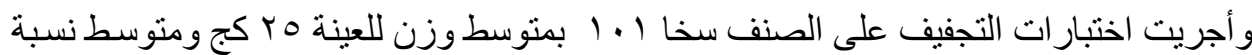

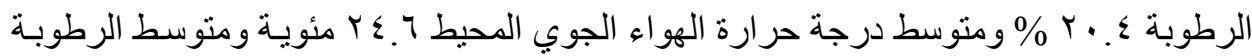

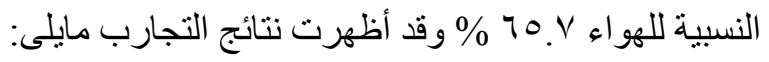

' ل مدرس الهندسة الزراعية - كلية الزراعة - جامعة الأزهر - القاهرة. باحث أول بمعهل بحوث الهندسة الزراعية ـ الدقي ـ الجيزة ـ مصر. 


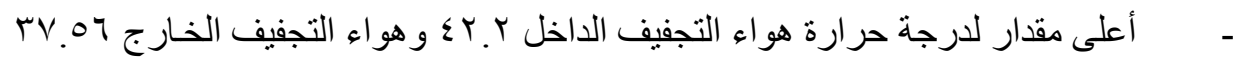

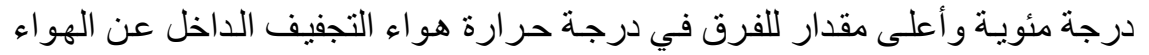

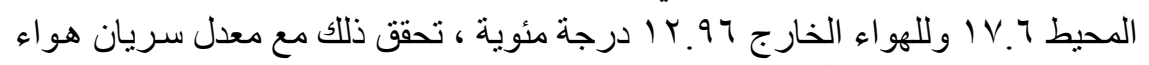

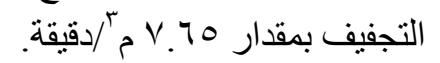

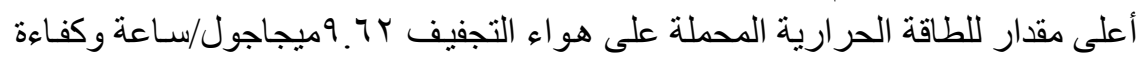

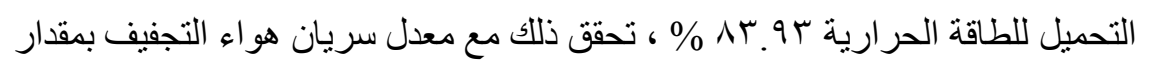

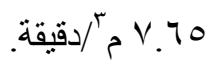

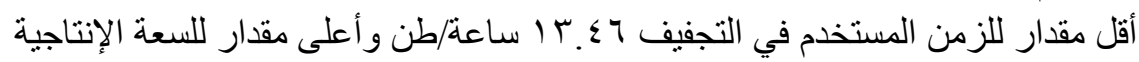

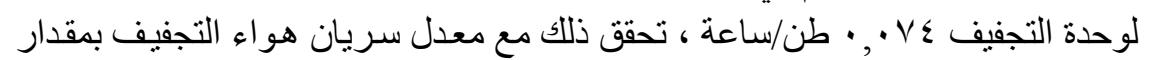

$$
\text { تص } 70
$$

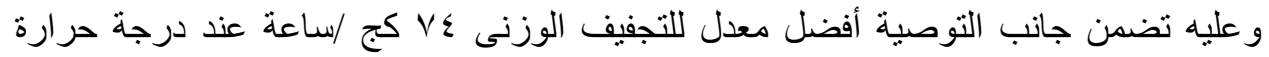

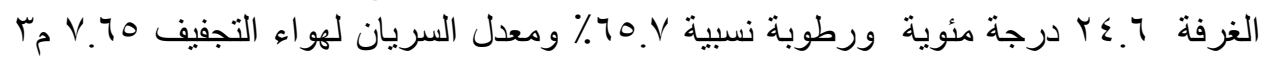

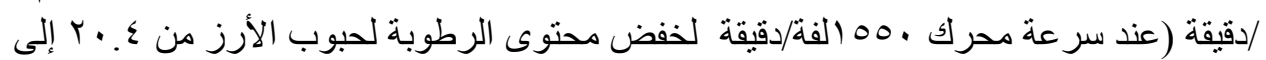
\% 1 1 . 7 